\title{
EMERGENCE OF SOCIO-ECONOMIC GEOGRAPHY AND SPATIAL MANAGEMENT AS A SCIENTIFIC DISCIPLINE IN THE NEW CLASSIFICATION OF SCIENCE IN POLAND ${ }^{1}$
}

\author{
TAdeUSZ STRYJAKIEWICZ ํ \\ Department of Economic Geography, Adam Mickiewicz University in Poznań, Poland
}

Manuscript received: April 8, 2021

Revised version: August 19, 2021

\begin{abstract}
StryJAKIEWICZ T., 2021. Emergence of socio-economic geography and spatial management as a scientific discipline in the new classification of science in Poland. Quaestiones Geographicae 40(4), Bogucki Wydawnictwo Naukowe, Poznań, pp. 7-14. 1 fig.

AвSTRACT: The aim of the article is to present the chronology of activities that led to the emergence of the discipline 'socio-economic geography and spatial management' in the new classification of science in Poland which has been in force since 2018. The path of emergence of the discussed discipline is analysed from the standpoint of one of the participants of this process. The article also presents positive and negative consequences of implementing this classification in the context of two different structural models of geography as a science. Among positive consequences one can mention (1) preservation of the name 'geography' on the list of scientific disciplines, and (2) a favourable formal and legal 'empowerment' of socio-economic geography in the system of the organisation and evaluation of science in Poland. Among the greatest threats one can see (1) a reduction in the importance of socio-economic geography in favour of spatial management, and (2) the organisational disintegration of some geographical communities, institutions and research units. However, there are also attempts at the reintegration of geography around two of its basic segments, i.e. physical geography and human geography. In the author's opinion, future activities should focus on the means to strengthen realistically (and not only declaratively) the position of the new discipline and its constituent subdisciplines against other scientific disciplines.
\end{abstract}

KEYWORDS: socio-economic geography, spatial management, classification of science, Poland

Corresponding author: Tadeusz Stryjakiewicz, Faculty of Human Geography and Planning, Adam Mickiewicz University, ul. Bogumita Krygowskiego 10, 61-680 Poznań, Poland; e-mail: tadek@amu.edu.pl

\section{Introduction}

The year 2018, celebrated as the Year of Polish Geography, revived discussion about the place of geography in the system of sciences and its social role. Apart from the historical factor (related

This article is an abridged and modified version of the paper published in Polish in Prace i Studia Geograficzne [Studies in Geography], vol. 65(2)/2020. to the 100th anniversary of the restoration of national independence and the emergence of institutional structures of geography in Poland), the proposals of the Ministry of Science and Higher Education on the new classification of science in Poland were a direct impulse that prompted the discussion. This classification (hereinafter referred to as the new classification) was drawn up in the form of the Ordinance of the Minister of Science and Higher Education of 20 September 2018 on the fields of science, and scientific and 
artistic disciplines (Rozporządzenie... 2018). This ordinance was issued following the implementation of the so-called Constitution for Science, and more precisely the Act of 20 July 2018 on higher education and science (Ustawa... 2018). The new classification replaced the previous one defined in the Ordinance of the Minister of Science and Higher Education of 8 August 2011 on areas of knowledge, fields of science and art, and scientific and artistic disciplines (hereinafter referred to as the old classification, Rozporządzenie... 2011). It meant significant changes for geography, becoming on the one hand, the object of criticism, and on the other, solving some problems that had been pressing for years.

The search for a place for our discipline in the new classification was not easy. The narratives developed around the process did not always reflect (and still do not) its real course. Therefore, this article attempts to present the path of emergence of the discipline 'socio-economic geography and spatial management' from the standpoint of one of the participants of this process.

Over the last years Polish geographers have repeatedly discussed the place of geography in the science system, its identity as well as its integration and disintegration tendencies (e.g. Bański 2010, 2013, Chojnicki (ed.) 2004, Degórski 2014, Domański, Widacki (eds) 1999, Lisowski 1996, 2007, 2012, 2016, Liszewski, Suliborski 2006, Łoboda 2004, Maik 2014, Parysek 2020, Plit 2013, Starkel, Wolski 2014, Stryjakiewicz 2016, Suliborski (ed.) 2016, Śleszyński 2020). In one of the articles cited above, entitled 'On the place of socio-economic geography in geography and the science system' published in Przeglad Geograficzny [Geographical Review] in 2012, Lisowski set himself the goal, among other things, of "showing arguments in favour of dividing geography - as a discipline composed of two basic disciplines: physical geography and socio-economic geography, assigned to two separate areas of science: natural and social sciences", stating at the same time that "in deliberations on the disintegration of the subject of geography, an institutional thread is becoming increasingly important (Lisowski 2012: 171, 185). It is this thread, relating to the place of geography in the classification of science in Poland, that will be developed in the following sections of this article.

\section{Socio-economic geography in the old and new classification of science in Poland}

The structure of the old classification of science in Poland embraced three levels: the area of science, the field and the discipline. Geography (both physical and socio-economic) ${ }^{2}$ was one of the four disciplines in the field of Earth sciences, in the area of natural sciences (next to geophysics, geology and oceanology). This situation and the lack of separateness of socio-economic geography entailed a series of difficulties of practical nature and the need to seek informal solutions. A good example can be obtaining academic degrees and titles. The post-doctoral and professorship procedures in the discipline of geography were formally proceeded in the Central Committee for Degrees and Titles (CCDT) in the section of hard and natural sciences ${ }^{3}$; socio-economic geography affairs, however, were referred to the section of economic sciences ${ }^{4}$. This kind of solution, operating for many years on a poorly formalised agreement within CCDT, raised a number of doubts from a legal point of view. It was also doctoral students, specialising, e.g. in social geography, who frequently expressed their dissatisfaction with the fact that they had to attend geology or glaciology classes as part of $\mathrm{PhD}$ studies, which were of little use in their future academic careers (similar dissatisfaction was expressed from the other side). Therefore, the need to look for new solutions was increasingly articulated. For many years, however, there were no external conditions for introducing any changes and the determination of the geographic community (outnumbered by the representatives of physical geography, close to other Earth sciences) was not strong. The reform of the science system in Poland undertaken in 2017-2018 by the Ministry of Science and

\footnotetext{
I use the term 'human geography' interchangeably with 'socio-economic geography'.

3 Hard and natural sciences encompassed the following disciplines: mathematics, computer science, astronomy, biophysics, physics, geophysics, biochemistry, biotechnology, chemistry, chemical technology, biology, biotechnology, ecology, microbiology, environmental protection, geography, geology, oceanology.

4 Economic sciences encompassed the following disciplines: economics, finance, management, commodity science.
} 
Higher Education provided such an opportunity. Notwithstanding the assessment of the assumptions and results of this reform (which varies considerably in the scientific community), one must admit that it created the possibility of the new 'empowerment' of geography (particularly socio-economic geography) in this system.

According to the Ministry of Science and Higher Education, one of the objectives of the new classification of science in Poland was to bring it closer to world classifications. There are obviously a lot of such classifications and their accuracy can be argued, but the fact that the classification offered by the Organisation for Economic Cooperation and Development (OECD 2007) was adopted as a certain model opened a 'window of opportunities' for socio-economic geography. This is so because this classification, among 40 scientific disciplines, singles out social and economic geography in the field of social sciences, while physical geography is one of the subdisciplines of Earth and related environmental sciences in the field of natural sciences ${ }^{5}$.

\section{Path to a new discipline}

It was not easy to give human geography its rightful place in the Polish classification of science. There were two-as it seems-basic reasons for that:

1. the position of socio-economic geography, and hence its bargaining power, in the structures of both science and geography itself is rather low in Poland; and

2. the community of Polish geographers (socio-economic geographers as well) were un-

Cf. Organisation for Economic Co-operation and Development (OECD), 2007. Revised Field of Science and Technology (FOS) Classification in the Frascati Manual. The introduction to this document reads, among other things: "...it is not realistic to think that it is possible to develop a classification that satisfies the needs of all actors involved. This is due to different perspectives of the scientific community, administrative systems, and users of the classification and to the dynamics of science itself (such as the emergence of interdisciplinary sciences). Therefore, the final classification represents a compromise between different viewpoints and user needs" (p. 2). This reflection is worth keeping in mind in all discussions concerning the classification of science and technology. decided - at least initially - about the direction the proposed changes should take ${ }^{6}$.

The body that played an important role in the formulation and evaluation of the first version of the new classification of science in Poland was the CCDT, where this issue was addressed many times at the meetings of its Presiding Committee and individual sections. The position of the economic sciences section of CCDT of 10 October 2017 included the words that there are arguments for separating the discipline of socio-economic geography and spatial management'.

It should be mentioned here that in this proposal a long English expression used in the OECD classification specifying the scope of the discipline-environmental sciences (social aspects); cultural and economic geography; urban studies (planning and development); transport planning and social aspects of transport (transport engineering to be civil engineering) - was deftly 'translated' into Polish, defining the name of the new discipline as 'socio-economic geography and spatial management'. Thus, the name 'geography', with its centuries-old tradition, has not been eliminated from the list of scientific disciplines. On the other hand, 'spatial management', the representatives of which for many years strived also for singling it out as a field or discipline of science, could be found for the first time in the official classification of science (not even being in the OECD classification). The above proposal was supported by the Committee of Geographical Sciences of the Polish Academy of Sciences (PAS). Despite numerous doubts, this position was also positively received by the participants of the annual Conference of directors of geographical units held at the University of Warsaw in November 2017. A different position was adopted by the Executive Group of the Union for Development of Spatial Management Studies, which submitted a letter of protest to the Minister of Science and Higher Education after the meeting of its representatives in Poznan. The actions described above, taken also by other environments (e.g. Committee of Deans of the Faculties of Geodesy, Polish Association for Spatial Information), resulted in the emergence of alternative projects concerning the classification of science in Poland. The most

6 Lisowski (2007) called this group of geographers 'situationists'. 
widespread was the one (dated 21 January 2018) in which socio-economic geography and spatial management would disappear as a separate discipline in the field of social sciences, and 'geodesy and geospatial engineering' would emerge in the field of engineering and technical sciences. There appeared many other conceptions as well, but the vast majority of them were aimed-against the Ministry's intentions-at increasing the number of disciplines, not reducing them. This inconsistency with the legislator's intentions, pro-active actions of a group of geographers (especially from Krakow and Warsaw scientific centres supported by the opinions of the Committee of Geographical Sciences of PAS and the Polish Geographical Society) and also the placement of social and economic geography as one of the disciplines of social sciences in the annexe to the opinion of the Scientific Policy Committee on the conception of the new classification of fields and disciplines $^{7}$ caused the project of the Ordinance of the Minister of Science and Higher Education on the fields of science, and scientific and artistic disciplines of 31 July 2018 not to be much different from its original version, and socio-economic geography and spatial management returned to its place. This place-despite successive proposals of changes brought forward by different scientific communities - remained in the final version of the Minister's Ordinance.

\section{Consequences of separating 'socio- economic geography and spatial management' in the new classification of science}

The consequences of separating 'socio-economic geography and spatial management' as a scientific discipline in the field of social sciences (and simultaneously subordinating physical geography to the discipline 'Earth and related environmental sciences' in the field of hard and natural sciences) can be considered in the category of both opportunities and threats. The greatest chances are connected with the perspective of a more equal position of human geography in

In the proposal of the Scientific Policy Committee, spatial management did not appear at all. relation to widely understood physical geography in the structure of science in Poland (not only in terms of substance, but also in terms of organisation). Therefore, this is essentially about returning to the general model of geography which I call 'balanced', propagated, among other scholars, by Leszczycki (1962), in which proportions between physical geography (divided into subdisciplines, such as geomorphology, hydrology, climatology etc.) and socio-economic geography (with such subdisciplines as, e.g. settlement and population geography, agricultural geography, geography of industry, transport and services, political geography, cultural geography) are fairly equal (Fig. 1).

I realise that appealing today to the division of geography into the examples of subdisciplines presented above is somewhat anachronistic ${ }^{8}$, nonetheless the idea itself of balancing the proportion and significance of the two principal elements of geography (one of which is more related to natural sciences and the other to social sciences) seems reasonable, regardless of the growing importance of interdisciplinarity in research and the emergence of numerous, more modern classifications of geography ${ }^{9}$.

In one of my previous articles (Stryjakiewicz 2016), I drew attention to the fact that the institutional structures of geography in Poland had been dominated by a model in which one of the subdisciplines of physical geography (most often geomorphology) was prevailing, and its essence

A detailed discussion concerning this issue is not covered in this article.

9 I personally advocate the relational approach in geography (cf. Stryjakiewicz 2016). However, in the institutional structures of geography in Poland (e.g. organisational units of faculties or institutes, commissions of the Polish Geographical Society), the division into subdisciplines related to particular components of the natural environment or human activity is still the most common, and the models shown in Figure 1 reflect this real situation (although modern trends in scientific development, especially GIS, increasingly 'dilute' the above dichotomy of geography). Therefore, my viewpoint presented in this chapter does not mean that the new classification of science will be geared to the conservation of the previous institutional structures. On the contrary, there is an opportunity to change them, not necessarily to the detriment of geography as a scientific discipline and its unity. Taking this chance will depend on the future activity of the geographic community. 

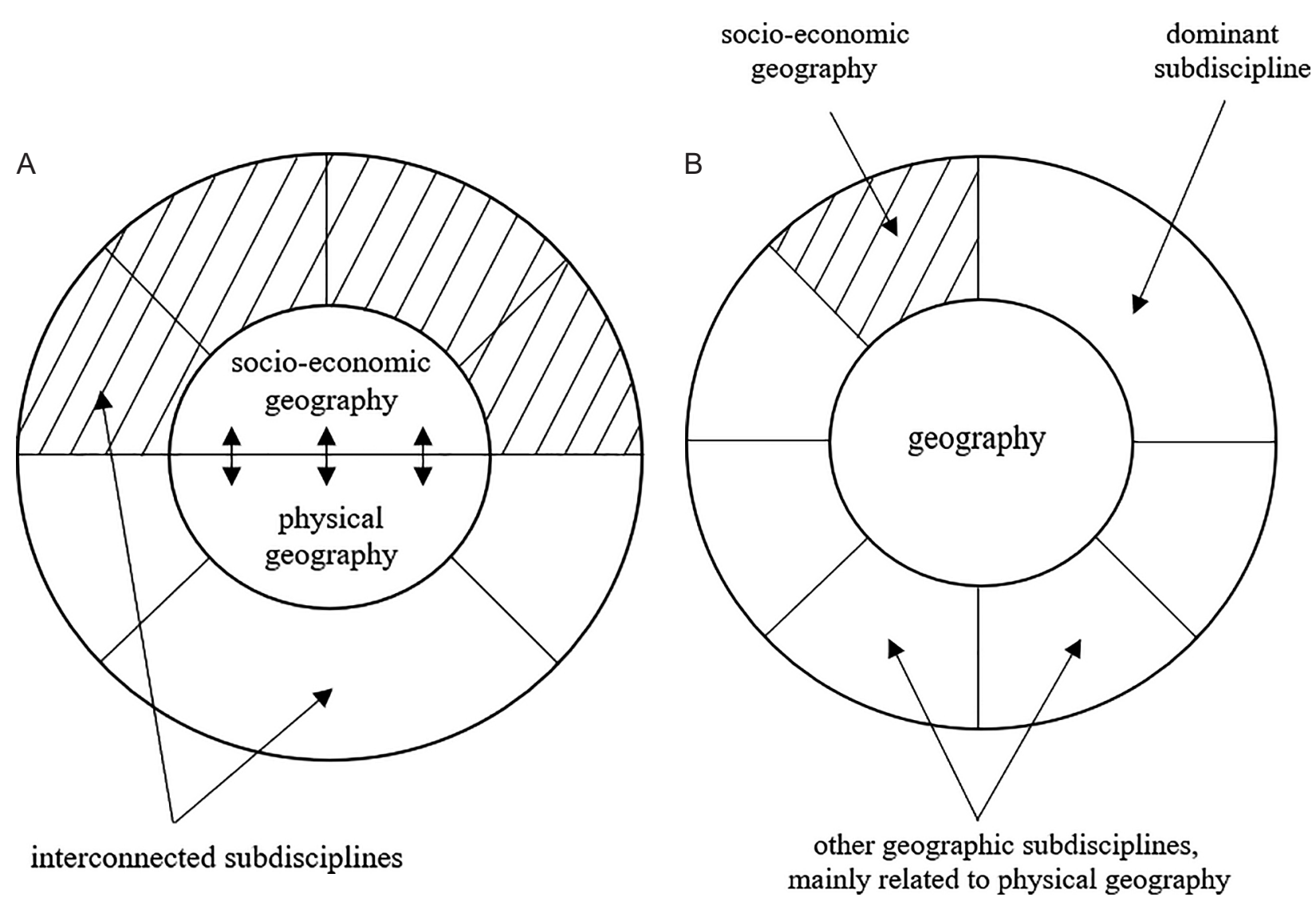

Fig. 1. Position of socio-economic geography in two separate structural models of geography as a science.

(A) Model of balanced proportions between physical geography (with its subdisciplines) and socioeconomic geography (with its subdisciplines). (B) Model in which socio-economic geography is one of many geographical subdisciplines.

Source: own elaboration.

was "greater concern about the preservation of the position of a dominant subdiscipline than concern about the development of geography as a whole (and much less socio-economic geography)" and that "this model departs from global standards" (Stryjakiewicz 2016: 71-72). The departure from the 'model of balanced proportions' presented above, has entailed at least two-in my opinion-adverse trends in the development of geography:

- gradual departure from using the name 'geography', pushing it out of the public awareness and replacing it with such synonymous (but still not identical) names as 'Earth sciences', 'geoecology', 'spatial management', 'regional studies' etc. ${ }^{10}$; and

10 Specialists on marketing would say that geography started to lose its brand. Lisowski (2012: 18) discusses "continuous elimination of the signboard 'geography' from the names of scientific and teaching institutions". This trend has been advantageous from
- rivalry between geographical subdisciplines for gaining a dominant position at the expense of geography as a whole (understood as the science of interactions between the natural environment and human activity).

These tendencies are also expressed in the names of some organisational units related to geography (e.g. there are several Faculties of Earth Sciences and Spatial Management at Polish universities, not having geography in their name). It was many years ago that I wrote about and discussed this issue, especially during the intergenerational discussion 'State, perspectives and the development strategy of socio-economic geography...' (Stryjakiewicz 2016).

the standpoint of the attractiveness of didactic offers, although it is not always conducive to self-identification and the consolidation of the identity of geography as a scientific discipline against other disciplines. 
Paradoxically, the introduction of the new classification of science stimulated discussion on the unity of geography and I am convinced that it may be conducive to halting the adverse trends outlined above. In addition to looking for interdisciplinarity in strengthening links with other sciences, one may wish to strengthen more the 'interdisciplinarity' (approved at present by the new classification of science) within geography. This would be a reference, among others, to the views of Lisowski expressed in the statement: "The unity of geography can be preserved by the reintegration of the discipline around two of its basic segments. A model 'two in one' seems more useful than searching for a 'spirit of unity' in the unity of geography understood traditionally" (Lisowski 2012: 191, cf. Liszewski, Suliborski 2006, Starkel, Wolski 2014). Likewise, Bański (2013: 294) is of the opinion that "dualism is (..) the strength of geography."

Another positive consequence of separating socio-economic geography and spatial management in the new classification of science, and at the same time an opportunity for the future, is a favourable formal and legal 'empowerment' of socio-economic geography in the system of the organisation and evaluation of science in Poland. Today, this discipline has as many as three representatives in the Council of Scientific Excellence (the same as economics and finance, sociological sciences or legal ones); also the evaluation of scientific achievements (and the related categorisation of organisational units) will take place within a reasonably homogeneous discipline, which should entail more objective assessments. One may say: it has never been better.

Among the greatest threats one can see the organisational disintegration of the present discipline 'geography', i.e. of scientific communities and related organisational units. The first experiences show, however, that it does not have to be so. The transformation of particular organisational units seems to go more smoothly in those geographical centres where the previous institutional model of geography was closer to the balanced one presented earlier. Problems arise most often in centres that significantly differ from this model.

Another threat, which in some cases has become a reality, concerns a loss of powers to confer academic degrees and titles regarding socio-economic geography, especially in relation to post-doctoral and professorship procedures ${ }^{11}$. On the other hand, these powers have been taken over, or are being claimed, by units that have not been formally geographical so far, and which develop research on spatial management and regional studies (e.g. the former Faculty of Economics of the University of Szczecin, Faculty of Geodesy, Geospatial and Civil Engineering of the University of Warmia and Mazury). In the further perspective, this may lead to a reduction in the importance of socio-economic geography in favour of spatial management in the discipline of 'socio-economic geography and spatial management', and also to the emergence of new centres of research.

\section{Final remarks}

The experience gained so far shows that the question of relationships between the two bodies of a new discipline is becoming very important with respect to its future. Several conclusions can be drawn here:

1. There is a need to better coordinate activities of scientific communities and institutions connected to the widely understood knowledge of space and the geographical environment.

2. The formulated postulates and propositions of the institutional 'empowerment' of this knowledge must take into account a broader context (particularly external circumstances, potential against other disciplines, 'compatibility' in relation to international classifications).

3. Excessively 'rigid' connection of scientific disciplines with courses of studies is not fully justified.

4. Future activities should focus on the means to strengthen realistically the position of a new discipline and its constituent subdisciplines.

I realise the reflections presented in this article are highly subjective and may seem controversial. The point of view and assessment of the introduced changes regarding the classification of

11 There are no obstacles, however, to reapply for those powers after meeting the criteria specified in the Act on higher education and science (Ustawa... 2018). Some geographical units have already done that. 
Polish science (and not only this issue) depends as always - on 'where you sit'. Time will verify those changes. Undoubtedly, we are at a turning point in the development of socio-economic geography in Poland, which in the conception of path dependence is defined as critical juncture ${ }^{12}$. The conception of path dependence closely links such a turning point to the events and processes preceding them. A new place of human geography in the classification of science in Poland results from many years of efforts, which Lisowski (2012) summarised as follows:

- "the rivalry between natural and social components of geography in Poland was related to the pursuit of separating a social component" (p. 181), and

- "contemporary geography reached a stage that requires reintegration, in which greater independence of socio-economic geography is an essential element" (p. 189).

\section{References}

Arthur B., 1994. Increasing returns and path dependence in the economy. University of Michigan Press, Ann Arbor. DOI 10.3998/mpub.10029.

Bański J., 2010. Stan krytyczny polskiej geografii - krytyka stanu (The critical condition of Polish geography - and a criticism of the current state of affairs). Przeglad Geograficzny 82(3): 319-333. DOI 10.7163/PrzG.2010.3.1.

Bański J., 2013. Jaka geografia? - uwarunkowania i spojrzenie $\mathrm{w}$ przyszłość (What kind of geography? - determinants and a glimpse into the future). Przeglad Geograficzny 85(2): 301-317. DOI 10.7163/PrzG.2013.2.7.

Chojnicki Z. (ed.), 2004. Geografia wobec problemów teraźniejszości i przysztości (Geography and its present and future problems). Bogucki Wydawnictwo Naukowe, Poznań.

Degórski M., 2014. Co nam zostało z tych paradygmatów, czyli krytyczne spojrzenie na geografię fizyczną w ostatnim 30-leciu w Polsce (What has left from these paradigms, or a critical view of physical geography over the last 30 years in Poland). In: Maik W., Suliborski A., Rembowska K. (eds), Dorobek polskiej geografii po konferencji w Rydzynie. Ocena krytyczna (The output of Polish geography after the conference in Rydzyna. A critical assessment). Wydawnictwo Uniwersytetu Łódzkiego, Łódź: 77-91.

Domański B., Widacki W. (eds), 1999. Geografia polska u progu trzeciego tysiaclecia (Polish geography on the threshold of the third millennium). Uniwersytet Jagielloński, Krakow.

Gwosdz K., 2004. Koncepcja zależności od ścieżki (path dependence) w geografii społeczno-ekonomicznej (Conception of path dependence in socio-economic geography). Przeglad Geograficzny 76(4): 433-456.

12 The conception of path dependence is presented, e.g. in the works of Arthur (1994), Mahoney (2000) and Gwosdz (2004).
Leszczycki S., 1962. Rozwój myśli geograficznej (Development of geographical thought). In: Geografia Powszechna, vol. 1, Ziemia - środowisko naturalne człowieka (Earth the natural environment of a human being). PWN, Warsaw: 20-56.

Lisowski A., 1996. Tendencje dezintegracyjne i integracyjne we współczesnej geografii człowieka (Disintegration and integration tendencies in contemporary human geography). Przeglad Geograficzny 68(3-4): 317-333.

Lisowski A., 2007. Przedmiot badań, funkcje i tożsamość geografii na początku XXI w. (Subject of research, functions and the identity of geography in the early 21st century). In: Maik W., Rembowska K., Suliborski A. (eds), Geografia a przemiany wspótczesnego świata. Podstawowe idee $i$ koncepcje w geografii (Geography vs changes in the contemporary world. Basic ideas and conceptions in geography), vol. 3. Wyższa Szkoła Gospodarki, Bydgoszcz: 39-54.

Lisowski A., 2012. O miejscu geografii społeczno-ekonomicznej $\mathrm{w}$ geografii i systemie nauki (On the place of socio-economic geography in geography and the science system). Przeglad Geograficzny 84(2): 171-198. DOI 10.7163/PrzG.2012.2.1.

Lisowski A., 2016. Stan, perspektywy i strategia rozwoju geografii społeczno-ekonomicznej (State, perspectives and the development strategy of socio-economic geography). In: Suliborski A. (ed.), Stan, perspektywy i strategia rozwoju geografii spoteczno-ekonomicznej w najbliższych latach (do 2030 r.). Dyskusja międzypokoleniowa (State, perspectives and the development strategy of socio-economic geography in the coming years (up to 2030). Intergenerational discussion). Wydawnictwo Uniwersytetu Łódzkiego, Łódź: 49-68.

Liszewski S., Suliborski A., 2006. Jedność geografii a problem kształcenia akademickiego (Unity of geography vs the issue of academic education). Czasopismo Geograficzne 77(1-2): 3-22.

Łoboda J., 2004. Stan i perspektywy polskiej geografii w opinii geografów (The state and perspectives of Polish geography in the opinions of geographers). Przeglad Geograficzny 76(4): 389-414.

Mahoney J., 2000. Path dependence in historical sociology. Theory and Society 29(4): 507-548. DOI 10.1023/A:1007113830879.

Maik W., 2014. Refleksje dotyczące polskiej geografii społeczno-ekonomicznej. Komentarze po trzydziestu latach od konferencji w Rydzynie (Reflections on Polish socio-economic geography. Remarks thirty years after the conference in Rydzyna). In: Maik W., Suliborski A., Rembowska K. (eds), Dorobek polskiej geografii po konferencji w Rydzynie. Ocena krytyczna (The output of Polish geography after the conference in Rydzyna. A critical assessment). Wydawnictwo Uniwersytetu Łódzkiego, Łódź: 219-242.

Organisation for Economic Co-operation and Development (OECD), 2007. Revised Field of Science and Technology (FOS) Classification in the Frascati Manual. Online: https://www.oecd.org/science/inno/38235147.pdf (accessed: 11 December 2019).

Parysek J.J., 2020. Polska geografia społeczno-ekonomiczna (i gospodarka przestrzenna) w okresie przełomu. Kilka wybranych refleksji (Polish socio-economic geography (and spatial management) in the period of transition. Some selected thoughts). Prace i Studia Geograficzne 65(2), 
Wydział Geografii i Studiów Regionalnych Uniwersytetu Warszawskiego, Warsaw: 33-56.

Plit F., 2013. O sporze pokoleniowym w polskiej geografii i jego uwarunkowaniach (On the generational dispute in Polish geography and its determinants) Przeglad Geograficzny 85(4): 655-675. DOI 10.7163/PrzG.2013.4.7.

Rozporządzenie..., 2011. Rozporządzenie Ministra Nauki i Szkolnictwa Wyższego z dnia 8 sierpnia 2011 r. w sprawie obszarów wiedzy, dziedzin nauki i sztuki oraz dyscyplin naukowych i artystycznych. Dz.U. 2011 nr 179 poz. 1065 (Ordinance of the Minister of Science and Higher Education of 8 August 2011 on areas of knowledge, fields of science and art, and scientific and artistic disciplines. Journal of Laws 2011, No. 179, item 1065). Online: http://prawo.sejm.gov.pl/isap.nsf/ DocDetails.xsp?id=WDU20111791065 (accessed: 11 December 2019).

Rozporządzenie..., 2018. Rozporządzenie Ministra Nauki i Szkolnictwa Wyższego z dnia 20 września 2018 r. w sprawie dziedzin nauki i dyscyplin naukowych oraz dyscyplin artystycznych. Dz.U. 2018 poz. 1818 (Ordinance of the Minister of Science and Higher Education of 20 September 2018 on the fields of science, and scientific and artistic disciplines. Journal of Laws 2018, item 1818). Online: http:/ / prawo.sejm.gov.pl/isap.nsf/ WDU20180001818 (accessed: 11 December 2019).

Starkel L., Wolski J., 2014. Polish geography: Does the past have a future? An interview with Professor Leszek Starkel. Geographia Polonica 87(3): 441-469. DOI 10.7163/ GPol.2014.30.
Stryjakiewicz T., 2016. Stan, perspektywy i strategia rozwoju geografii społeczno-ekonomicznej w najbliższych latach (do 2030 r.) (State, perspectives and the development strategy of socio-economic geography in the coming years (up to 2030). In: Suliborski A. (ed.), Stan, perspektywy $i$ strategia rozwoju geografii spoteczno-ekonomicznej w najbliższych latach (do 2030 r.). Dyskusja międzypokoleniowa (State, perspectives and the development strategy of socio-economic geography in the coming years (up to 2030). Intergenerational discussion). Wydawnictwo Uniwersytetu Łódzkiego, Łódź: 69-75.

Suliborski A. (ed.), 2016. Stan, perspektywy i strategia rozwoju geografii społeczno-ekonomicznej w najbliższych latach (do 2030 r.). Dyskusja międzypokoleniowa (State, perspectives and the development strategy of socio-economic geography in the coming years (up to 2030). Intergenerational discussion). Wydawnictwo Uniwersytetu Łódzkiego, Łódź.

Śleszyński P., 2020. Geografia wobec wyzwań systemowej reformy nauki w Polsce (Geography and its challenges of the systemic reform of science in Poland). Prace i Studia Geograficzne 65(2): 57-69.

Ustawa..., 2018. Ustawa z dnia 20 lipca 2018 r. - Prawo o szkolnictwie wyższym i nauce. Dz.U. 2018 poz. 1668 (Act of 20 July 2018 on higher education and science. Journal of Laws 2018, item 1668). Online: http:/ / prawo.sejm. gov.pl/isap.nsf/DocDetails.xsp?id=WDU20180001668 (accessed: 11 December 2019). 